\title{
THE EFFECT OF "DAR"" RULE (A PREVENTION LAW) IN CONVERSION OF RETALIATION(QISAS) TO BLOOD MONEY(DIYA)
}

\author{
Yahya Aryamanesh ${ }^{1}$ \\ Mohammad Adibi Mehr ${ }^{2}$ \\ Mohammad Javad Baghizadeh ${ }^{3}$ \\ Davood Dadash Nezhad ${ }^{4}$
}

\begin{abstract}
One of the important rules of jurisprudence that has been considered by jurisprudents and lawyers is the Dar' (obviation) rule, which is referred to as "obviation of punishments in case of doubt". Although the Dar' rule is applied in hadd (Islamic punishable crime) offence, according to the provisions of the rule, in the cases where the occurrence of a crime or its assignment to the accused or deserving punishment is doubtful and suspicious, the crime and punishment should be ruled out according to this rule. Today, most jurisprudents consider other offences subject to the rule and believe that Hudud means all punishments. In this
\end{abstract}

article, the results of the inclusion of the rule of Dar' in Qisas and its conversion into Diya is addressed.

Keywords: doubt, Dar', Qisas, punishments.

\section{Introduction}

According to some jurisprudents, as Qisas is one of the rights of people and the basis of the rights of people is precision, if there is a doubt about Qisas, this rule cannot be considered. In addition, the rational principles, such as the principle of nonnegligence, non-misguidance, reluctance, etc., prevent the course of the

\footnotetext{
${ }^{1}$ Ph.D. student, School of Jurisprudence and Islamic law, Damghan Branch, Islamic Azad University, Damghan. Iran. Email: yahya1977@chmail.ir.

${ }^{2}$ Associate professor, Jurisprudence and Islamic Law of Farabi Campus, Tehran University, Tehran, Iran. Email: madiby@ut.ac.ir

3 Assistant Professor of Jurisprudence and Islamic law, Damghan Branch, Islamic Azad University. Damghan, Iran. Email: baqizadeh@gmail.com.

4 Assistant Professor of Jurisprudence and Islamic law, Damghan Branch, Islamic Azad University. Damghan, Iran. Email: dadashnejaddavood@yahoo.com
} 
matter under discussion. On the other hand, these principles do not apply for Hudud (because the divine Hudud are based on discount and tolerance); but this is not the case in Qisas, which is part of the rights of people and there is a need for precision. Therefore, in case of raising doubt by the ruler, accused or both, the ruler must precede with the abovementioned rational principles i.e. he should not rule out Qisas as an example of rights of people in case of doubt. Therefore, the flow of these principles prevents the flow of the rule under discussion in Qisas.

In contrast, some believe that Qisas is in fact divine Hudud because divine Hudud are not exclusive to whipping; but any punishment imposed by the Almighty God "and whoever is slain unjustly, We have indeed given to his heir authority" (AL-ISRA, 33).

\section{The meaning and the notion of doubt}

a-Linguistic Meaning: The term doubt means suspicion, suspense, mistake and confusion between right/wrong, just /unjust and reality/fiction.

The owner of the Qur'an's thesaurus (Qamus) writes: doubt refers to the case that two things are not distinguished from each other due to their similarity (Qureshi, Qur'an's Qamus, 2: 235). According to the Qur'an: "and they did not kill him nor did they crucify him, but it appeared to them so" (AN-NISA, 157).

b- The concept of doubt: in jurisprudence, Imamiyah jurists disagree on the interpretation of doubt; some have said that doubt in jurisprudence and based on this rule means lack of science and certainty on the sanctity prohibition of the act or the abandonment of the sin, which is subject to suspicion, doubt and probability. Others also believe that doubt is the suspicion on the (im)permissibility of an impermissible act. Some have also considered it as suspicion.

\section{The Author of Mabani Takallamah} alminhaj writes

The notion of doubt that rules out the death penalty is negligence or ignorance of a forbidden act if the perpetrator believes in permissibility of the act before and during the commitment. However if the accused is ignorant of the rule but he is aware of his 
ignorance during committing the crime, the punishment for adultery will be due for him (Khoei, 2011, p. 169).

By conveying the notion of "With the belief of Al-Helliyeh" he considers doubt as supreme ignorance i.e. with the belief in the permissibility of the act.

The author of Riyadh writes about the meaning of doubt: If a perpetrator of a forbidden act is suspicious about the (im) permissibility of the act, he will not be punished (Najafi, 1850, p. 262).

Shahid Sani stated in his book: The rule of the doubt that rules out the punishment is that the perpetrator of the forbidden act considers the likelihood of permissibility of that act because the rule "Dar' borders suspicions" is applicable to public and includes permissibility, doubt about permissibility and suspicion about it. Therefore, doubt refers to doubting or suspicion on (im)permissibility and includes all these definitions. In case of the existence of doubt, the punishment will be ruled out.

\section{The meaning of Tadra' (Dar')}

The word Tadra' is derived from the root (Dar') meaning dismissal, rejection and exclusion. The Holy Qur'an mentions "and repel evil with good" (AL-RAD, 22) or "Say: Then avert death from yourselves if you speak the truth" (AL-E-IMRAN, 168).

It also means denying and repelling punishment in the Qur'an “And it shall avert the chastisement from her if she testify four times, bearing Allah to witness that he is most surely one of the liars" (AL-NOOR, 8).

The author of Majma-olBahrein under the aforementioned verses states the Hadith of 'Dar' borders suspicions" and states "cause" means by means of doubts, people are excluded from punishments.

\section{Sanctions Cause Suspicion}

In accordance with the principle of Dar's, which states that "Sanctions cause suspicion", Hudud are repelled by doubts; the general concept is that in cases that the commission of a crime or its assignment to the accused or the liability and the desirability of punishment is subject to doubt, the crime and punishment should be ruled out.

Based on 'Dar' borders suspicions" Hadd is defined by a number of criminal acts, each of which has a 
definite punishment. However, the question arises as to whether the mere general conformity of an individual means that Haa refers to certain punishment and it does not include Qisas and ta'zir. Is there any trope in this regars?

Considering the narratives and other arguments, it seems that Hadd means punishments and because of its recurrence over time, it was used in this sense. However, it is used in (non) deterministic punishment in relation to the general conformity with one of examples or individuals. Otherwise, there is no evidence of a Qur'an, narrative that proves that the term Hadd is certain in deterministic punishment, and using it in this sense requires an example.

However, the fact that the public and Imamiyah jurists have accepted that Hadd means certain punishment has no reason. Although this concept has become common in the language of the jurists in the past and present, this only proves the jurists' truth rather than the truth of sharia. However, the basis of understanding the true meanings of the terms of the traditions is their true meaning at the same period rather than later times.

\section{The viewpoints of the Jurists}

198

Sheikh Tusi in Mabsut, Shahid Sani in Mesalak, Majlesi in Rozat-olmottaghinm Seyyed Mohammad Javad Ameli in Meftah al-Karama in his quoting on Kashf-ol-la'am and Mirza Qomi in al-Shatat explicitly mention that this rule includes Qisas.

Mohaghegh Ardebili in Majmaal-Qaida and Aborhan the author of Jawahir mention in exclusion. Sheikh Tusi writes in Mabsut:

Qisas is also applicable in teeth ... This is if the victim survives. In the event of death, if death has occurred after the despairing about the tooth regrowth, the accused is liable but the victim is free to choose Qisas or Diya. If the victim passes away before despairing about the tooth regrowth, Qisas is ruled out because hudud is repelled by doubt. The case of doubt is that one does not know whether the tooth will regrow or not. (Tusi, 2009, p. 97) 


\section{Shahid Sani in Masalek says:}

When an apostate repent but someone kills him due to thinking that he is still a denier, there is doubt on his Qisas. The reason for the lack of Qisas is that the killer does not intend to kill someone that he is forbidden to kill even though he was intended to kill him. Another reason that Qisas is Hadd is that the meaning of the term is also realized in Qisas and the suspicion of the assassin about the denial of the victim is a kind of doubt, and Qisas is repelled with this doubt. In this case, the Diya of murder because his murder is a manslaughter (Shahid Sani, 1992 :40).

$\begin{array}{ccc} & \text { Molla } & \text { Mahammad Taghi } \\ \text { Majlesi in } & \text { Rozat-ol-mottaghinm }\end{array}$

following the narrative says:

"Hudud" includes the ta'zir and Qisas Hudud and "doubts" include any mistake even if the doubt is due to the conflict of evidence or the absence of reason in appearance (Majlesi, 1986: 229).

\section{Seyyed Mohammad Javad}

Ameli in his quoting on Kashf-ol-la'am says: victim on the dementia of the criminal during the crime, even if the victim is claiming dementia due to the drunkenness and the criminal is claiming dementia due to madness, the claim of the criminal is prior even if he does not have a history of dementia due to the principle of innocence and mutiny to both meanings and the existence of doubts (Ameli, 2000, p. 20)

However, in another matter, he says:

If someone amputates another person's hand and the victim claims contagion of that scar (and the death of the victim because of it), but the criminal claims its healing, the criminal's claim is prior because of the principle of innocence that the appearance supports the whole (because usually amputation do not result in death) due to the existence of doubt (ibid: 197).

In addition, the author of Meftah al-Karama quotes Mabsut and considers it allowable (ibid: 184).

If there is a conspiracy between the criminal and 
Mirza Qomi in al-Shatat mentions a question and its answer:

Question: Zeyd takes Omar and Bakr to protect his property at night and they slept in the night at Zeyd's house, and in the morning, the suffocated bodies of them were in his house and the murderer was unknown. Do the avengers of blood ask for diya from Zeyd?

Answer: Once he has taken them on the day and they have begged him to protect their property, the problem is suspicious...

And whenever he calls them in the night and took them to his house without being asked to do so, and then they are found dead in his house, this is a well-known issue that the jurists have ruled: whenever someone calls another one in the night out of his house, he is the guarantor to bring him back home and all jurists agree on this matter as a group have claimed. So we say that: It is either that the person who has been taken out of the home is lost and his death is unknown or he is not missing...

However, if the person is found dead, either he is killed, suspected of crime or dead naturally...

Therefore, if it turns out that he has killed him and he confesses on murdering him, he will be subject to Qisas. However if it turns out that another person has killed him or he confesses to murder, the liability of the first person is ruled out.

Whenever there is no confession between and that person does not sue another, he is not subject to Qisas and clearly, he is obligated to pay his diya. Because the liability mentioned in Hadith (Abdullah bin Meymoun and Amr ibn Abi al-Moghadam) is subject to diya and due to the doubt, he will be free from Qisas. Based on Dar' borders suspicions he will be liable to pay diya as a consensual settlement and Ibn Edris manioned that this is the most vivid statement of narratives and then Sheikh Mufid is quoted on the promise of Qisas...( Mirza Qomi, 1992: 729).

Mohaghegh Ardebili in Majmaal-Qaida and Aborhan writes:

"Killing his (murdered...) is not Hadd in terms of Qisas until the doubt is resolved as mentioned in Masalik. He adds that if we accept that there is doubt, it does not rule out Qisas as a human right even if Qisas is called had (Mohaghegh Ardebili, 2000: 443). 
However, Mohaghegh Ardebili says in another part of the book: The mad or child plaintiff who has committed murder in madness or childhood, their claim is accepted. That is, if it is proven that someone who is insane or child has committed murder, their claim is accepted with the vow because firstly: they have been mad or child before and the principle of the non-deterioration are applicable in the case of murder (ibid 14: $10)$.

Secondly, Qisas for murder is applicable in maturation and improvement in health and the principle is the non-existence of these two, unless the existence of these two definitions is proved by a statement or confession, and it is assumed that it has not been proved and the two are denying. Therefore, their claim is accepted.

Thirdly, the defendant claims to be the murderer and these two are denied.

Fourthly, here doubt will rule out Qisas

It may seem that the lack of precedence of murder is the principle (on madness and childhood) and the cause of Qisas, which is the murder, is constant; therefore, ruling out the doubt requires a reason (ibid).

\section{The author of Jawahir writes:}

201

Some narratives imply that there is a contradiction between the concept of ta'zir and some of these narratives are contradictory. It cannot be denied that Hadd also refers to ta'zir. Therefore, in rulings that are contrary to the principles and generalities, the notion of Hadd refers to a kind of Hadd that is contrary to ta'zir.It is not that the one including ta'zir is powerless unless the discussion implies something else. If the term Hadd is intended in general sense, the lack of inclusion of Qisas in Hadd is strengthened. And God knows better (ibid: 257).

Some have also said that although in some cases the word Qisas has been used, this does not mean that the term "Hadd", which is used absolutely, refers to the meaning of Qisas without any indication and evidence because Hadd in Shari'a has a special interpretation and sentences. In addition, the Hadith of Sunan atTirmidhi indicate that in cases of Hadd, investigation is not required and this is inconsistent with the general notion of Hass, which contains Qisas and deliberate murder because investigation 
is obligatory in Qisas and deliberate murder.

Hadd and Qisas in narrations:

Narrations in this regard are divided into two categories: the first category indicates the exclusion of Qisas in Hadd and Hadd is against Qisas in some of them.

The second category Hadd includes Qisas so that Qisas is among the obvious examples of Hadd.

Narrations of the first category:

1- In al-wasael an Tahzib based on Ja'farban, Bashir Ali Maali bin Othman quoting Abi Abd Allah, peace be upon him, he said: Imam Sadiq (a) states that a person who dies due to Qisas or diya receives no diya (Horameli, 1996: 65).

The division of Hadd and Qisas in this narration indicates the contradiction between these two.

2- Imam Sadiq mentions that Hadd is not inherited (Ibid: 45, 46, 208 and 209)

It is obvious that Qisas Hadd is not inherited, therefore this had does not include Qisas. (ibid: 45)
The narrator says: I heard that Imam Sadiq (AS) said: Hadd is not inherited like money and land, but one of the heirs who wants to practice Hadd but it is Hadd and the one who does not claim has no right.

3- Imam Baqir (AS) says: Amir alMu'minin (AS) never wanted anyone to be forsaken from Hadd (ibid: 254)

While amnesty in Qisas is acceptable in the Qur'an.

4- » It is not within the Al-Hudud a positive viewpoint «(ibid: 47)

Amir al-Mu'minin (AS) said: there is no deadline in Hudud but in Qisas the avenger of blood has a deadline. In the book of Tahzib it is mentioned in a narrative that the ruler has to ask about the examples of Hudud, Qisas and execution to prove the claimant.

5- „ Every time a man saw Diya in Qisas, another Diya would not be involved with him. .«(Koleini, 2012: 290)

Imam Sadiq (AS) says: " a person who dies due to Qisas or diya receives no 
diya". It is likely that this narrative is a second category narratives, unless the word is in the narrative that the narrative would be: » Every time a man saw Diya in Qisas, another Diya would not be involved with him. That is, someone who is killed due to Qisas and diya receives no diya".

6- $»$ : The testimony of a woman is not permitted in Had and Qud cases. «(Horrameli, 1996:141).

Imam Ali (AS) said: "Women's testimony is not accepted in Hudud and Qisas. Imam Sadiq in explaining the reason of why murder requires two witnesses and adultery four witnesses to Abu Hanifa says "there are two Hadds in adultery (for women and men); therefore, it is not permissible unless there are two withnesses for these two Hadds. However, there is just one Hadd in murder exercised on the murdered. Therefore, it is sufficient to prove that by two witnesses. In the last part of this narration, Hadd means Qisas (Ibn Babaieh, 2001: 2\& 169).

This narration is like the previous one, but at the end "The murderer is based" the term Hadd is not used, which is the same in Mer'at-ol-
203

Oghool and in in Mer'at-ol-Oghool this Hadith is quited from Kafi without the term Hadd (Mer'at-ol-Oghool, 2:262).

\section{The need for caution in exercising Qisas}

The principle of precaution in some cases is the same as the rule of Dar'. This state is consistent with the doubts about the material element and the spiritual element of the crime. In this kind of doubt, the punishment of the accused is found to be in close proximity to the principle of caution; so that if the judge doubts whether the accused has committed a prohibited act or whether he has deliberately committed an illegal act, the accused should be free from the punishment under the principle of caution about the preservation and welfare of the Muslims. The principle of caution on the part of the judge can be expressed in another way that by doubting the material and spiritual element of the crime, the judge doubts whether the accused is subject to punishment or if he exercise Hadd or Dar' -al-Hadd. For example, he doubts whether the accused deserves Rajm. One the one hand the judge's duty is to perform the Divine Hadd and not 
delaying and on the other hand, according to the many traditions, divine punishments and Hadd are based on discount and tolerance and the legislator attempts to maintain the population of Muslims (Horrameli, 1996: 336).

Hence, the judge is obligated to take precautionary measures in such cases to rule out the punishment or consider discount in it. This case happen when there is doubt on Qisas and it becomes diya by observing the principle of caution.

\section{The incidence of doubt in Qisas and replacing Diya}

Obviousely, in penal code, diya has been introduced as one of the types of Islamic punishments.

The term Hudud in the rule of Dar' includes ta'zir and Qisas and it does not include diya because in the legal nature of diya, there is an argument whether it is a form of punishment or compensation!

With this doubt in the legal nature of diya, using the general sense of Hudud to include diya is not allowable because it has been proved in jurisprudence and mentioned in examples that using the general sense in
204

such cases is not correct. Therefore, there is no example in jurisprudence that a jurisprudent rules out diya based on the above rule because diya has been legislated by Islamic law to respect Muslim blood, which is considered as the financial rights of individuals. In the area of financial rights, the principle of precision is applied and in this field, the rational principles such as nonmisguidance, reluctance, neglect, and so on are applied. Consequently, the right of Muslim is not abolished by doubt. Of course, in some cases, the necessity of paying for diya is ruled out, which is rarely considered (Shahid sani, 1993, p. 363).

It should be noted that the effect of doubt on diya could be raised directly when Qisas is obligatory. Then, because of the doubt, the Qisas will be abolished. However, if diya is obligatory first, such as manslaughter and accident, it is clear that doubt is not effective.

\section{Conclusion}

Considering the narratives about the Dar` rule of it seems that Hass means punishment in the absolute meaning. 
It is irrelevant to deterministic punishments known as Hudud, and because of its recurrence over time, it was used in this sense. However, it is used in (non)deterministic punishment in relation to the general conformity with one of examples or individuals. Otherwise, there is no evidence of a Qur'an, narrative that proves that the term Hadd is certain in deterministic punishment, and using it in this sense requires an example.

In many cases, jurists have ruled out Qisas punishment with doubting about punishments such as Qisas. Therefore, considering the general comments of the jurists, it is clear that this rule also applies to Qisas. Considering the jurisprudential phrases regarding the inclusion of the rule of Dar' in case of Qisas, the general and Imamiyah jurists agree that Qisas is ruled out like Hudud under doubt but diya is obligatory.

\section{References}

The Holy Quran

Ibn Qadamed, Abdul Rahman, Great description, Beirut, Dar Al-Kutub AlArabi
Ardebili (Mohaghegh Ardebili), 1993, Ahmad, Majma-al-Qaida and Aborhan, Vol 13, Society of Qom's teachers, AlNashr al-Islami.

Asadi (Allameh Helli), Hasan Bin Youssef, 1992, The rules of the law, Vol3, Qom, Al-Nashr al-Islami

Horrameli, Muhammad b. Hassan, 1996, Wasael-ol- Shiite, Vol 15, Al-Alibat institution

Hosseini Rouhani, Mohammadsadegh, 1992, Sadiq Fighh, Vol 26, Qom, Dar Al-Kutub institution

Habid, Ibn Rushd, 1992, Bidaya almojtahid and nahaya almughtasid, Dar-al-Fikr

Halebi (Ibn Zohreh) Hamza ibn Ali 1997, Ghaniah ah nozou, Vol 1, Qom, Alamam Al-Asadq Institute

Helli (Mohaghegh Helli) Ja'far Benn Hassan, 1983, Sharae' al-Islam, Vol 4, Birout Dar-al- Azva'

Khomeini, Ruhollah, Tahrir-al-Wasile, Vol 2, Qom, Dar Al-Kutub Ismaeilian 


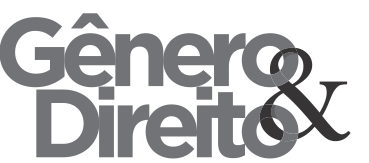

Periódico do Núcleo de Estudos e Pesquisas sobre Gênero e Direito

Centro de Ciências Jurídicas - Universidade Federal da Paraíba

V. 8 - $\mathrm{N}^{\circ} 01$ - Ano 2019

ISSN | 2179-7137 | http://periodicos.ufpb.br/ojs2/index.php/ged/index
Khoie, Seyyed Abolqasem, 1990,

Takallama minhaj Assalehin, Vol 28,

Nashr almadina alelm

Khansari, Sayyad-Ahmad, 1985, Jime'

al-Madarik, Vol 7, Tehran, Maktaba Asodugh

Shafei, Muhammad ibn Idris, 1983,

Kitan Al Imam, Vol 2, Beirut, Dar-al-

Fikr

Tabatabai, Seyyed Ali, 1984, Riaz an Masael, Vol 2, Qom, Aal al bayt institution

Tusi (Sheikh Tusi), Mohammad bin Hasan, 2008, Almabsout, Vol 7, Tehran, Almaktaba Almortazaviah

Ameli (Shahid Sani), Zayn al-Din al-Bin Ali, 1990, Rozah Albahieh, Vol 10, Qom, Davari pub

Albari Baghdadi (Sheikh Mofid), Mohammad bin Mohammad, 1990, Almoghnaeh, Vol 2, Qom, Jamea' almodarresin

Kashani, Aladdin Massoud, 1989, Badaye Alsanaye, Viol1, Pakistan, Almaktaba Alhabibiah
206 Maki Ameli (Shahid Awwal), Muhammad bin Jamal al-Din, 1991, Allamah Aldameshghiah, Viol1, Dar-alFikr

Najafi, Muhammad bin Hassan, 1989, Jawahir Alkalam, Vol 42, Tehran 